\title{
Orange-colored diapers in infants from families with gout
}

\author{
Kamal F. Akl
}

Received: 16 December 2010 / Revised: 10 January 2011 /Accepted: 11 January 2011 / Published online: 30 January 2011

(C) IPNA 2011

Sirs,

I read with great interest the article entitled "Orangecolored diapers as first sign of Lesch-Nyhan disease in an asymptomatic infant" by Gasperini et al. that was recently published in Pediatric Nephrology [1].

These authors made the point that orange-colored diapers after the neonatal period may indicate early manifestation of Lesh-Nyhan disease and that in such cases a metabolic disorder should be excluded. I agree with the authors that the production of orange urine by infants is

Table 1 Results of biochemical tests for three infants presenting with orange-colored urine

\begin{tabular}{llllll}
\hline Case & $\begin{array}{l}\text { Age at } \\
\text { onset } \\
(\text { months })\end{array}$ & Urine & $\begin{array}{l}\text { Serum } \\
\text { creatinine } \\
(\mathrm{mg} / \mathrm{dl})\end{array}$ & $\begin{array}{l}\text { Serum uric } \\
\text { acid (ua) } \\
(\mathrm{mg} / \mathrm{dl})\end{array}$ & $\begin{array}{l}\text { Urine } \\
\text { ua:cr } \\
(\mathrm{mg} / \mathrm{mg})\end{array}$ \\
\hline 1 & 3 & Urates & 0.52 & 4.6 & 3.0 \\
2 & 3 & Urates & 0.1 & 5.9 & 1.59 \\
3 & 7 & Urates & $\mathrm{NA}$ & $\mathrm{NA}$ & $\mathrm{NA}$ \\
\hline
\end{tabular}

For normal values for urate excretion, see Poyrazoglu et al. [3]

${ }^{\text {a }}$ Ceatinine:uric acid ratio not always benign and report here the cases of three infants who presented at Jordan University Hospital with orange urine. The findings of the biochemical tests are shown in Table 1. Family history was positive for gout in all three infants, and stones were found in cases 1 and 3 .

While orange urine may simply be a reflection of benign increased urinary uric acid concentration, more ominous disorders must be ruled out. It may be associated with metabolic disorder and morbidity [2].

A careful diagnosis is warranted, especially in the presence of a positive family history of gout.

\section{References}

1. Gasperini S, Stagi S, Gasperini U, Guerrini R, la Marca G, Donati MA (2010) Orange-colored diapers as first sign of Lesch-Nyhan disease in an asymptomatic infant. Pediatr Nephrol 25:2373-2374

2. Fujita T, Shimooka T, Teraoka Y, Sugita Y, Kaito H, Iijima K, Matsuo M, Nozu K, Tanaka R (2009) Acute renal failure due to obstructive uric acid stones associated with acute gastroenteritis. Pediatr Nephrol 24:2467-2469

3. Poyrazoglu HM, Düsünsel R, Yazici C, Durmaz H, Dursun I, Sahin H, Gündüz Z, Gürgöze MK (2009) Urinary uric acid: creatinine ratios in healthy Turkish children. Pediatr Int 51:526-529

\section{K. F. Akl $(\square)$}

Jordan University Hospital, College of Medicine,

University of Jordan,

P.O. Box 831373, Amman 11183, Jordan

e-mail: kachbl@yahoo.com 